\title{
THEFT IN THE CODICES PICTURATI OF THE SACHSENSPIEGEL
}

\section{Roubo nos codices picturati do Sachsenspiegel}

\author{
Professor Claudia Händl \\ Dipartimento di Lingue e Culture Moderne \\ Università degli Studi di Genova - Italy \\ ORCID: https://orcid.org/0000-0001-7771-7913 \\ E-mail: claudia.haendl@unige.it
}

Recebido em: 15/09/2020

Aprovado em: 15/12/2020

\begin{abstract}
My research is focused on the characteristics of the crime of theft and its punishment in Eike von Repgow's Sachsenspiegel, which was written between 1220 and 1235 in the Middle Low German language. The relationship between the text and images in the four codices picturati of this legal text will be examined in the context of some passages directly related to theft and its punishment to demonstrate that the illustrations in these manuscripts can contribute to a better understanding of legal institutions in the German Middle Ages.

Keywords: Sachsenspiegel - Eike von Repgow - medieval German law - theft interrelation of text and image in medieval manuscripts.

Resumo: Minha pesquisa está focada nas características do crime de roubo e sua punição no Sachsenspiegel de Eike von Repgow, que foi escrito entre 1220 e 1235 em Médio Baixo Alemão. A relação entre o texto e as imagens nos codices picturati neste texto legal será examinada no contexto de algumas passagens diretamente relacionadas ao roubo e sua punição para demonstrar que as ilustrações nos manuscritos podem contribuir para uma melhor compreensão das instituições jurídicas da Idade Média alemã. Palavras-Chave: Sachsenspiegel; Eike von Repgow; direito medieval alemão; roubo; inter-relação entre texto e imagem nos manuscritos medievais.
\end{abstract}




\section{Introduction}

Eike von Repgow's Sachsenspiegel, a legal text written between 1220 and 1235, is one of the first prose works written in the Middle Low German language. It contains two branches of law: common law (lantrecht) and feudal law (lenrecht). The Lantrecht section discusses important legal institutions concerning civil and criminal law and deals, among other things, with the crime of theft.

The Sachsenspiegel has been handed down in well over four hundred manuscripts and fragments, among which the codices picturati revest a particular position. The four surviving pictorial manuscripts from Dresden $(\mathrm{D})^{1}$, Heidelberg $(\mathrm{H})^{2}$, Oldenburg $(\mathrm{O})^{3}$ and Wolfenbüttel $(\mathrm{W})^{4}$ were created in the 14 th century and return to a common model generally dated to the end of the 13th century located in the Harzvorland (cf. von AMIRA, 1902; SCHEELE, 1992, I: 35-36; SCHMIDT-WIEGAND, 1992: 10).

My research is focused on the characteristics of the crime of theft and of its punishment in Eike's legal text. Theft is the act of secretly transferring, in a conscious and premeditated way, movable property from the custody (gewere, see OGRIS, 2009) of the owner to that of the thief. My intention is to show that in certain cases, the illustrations in the codices picturati of the Sachsenspiegel can contribute to a better understanding of legal institutions in the German Middle Ages.

\section{The offence of theft in the earlier Germanic legal records}

In contrast to open robbery, theft is considered a 'dishonest' misdeed from the outset. Germanic people regarded aggravated theft as one of the worst crimes (cf. BRUNNER/von SCHWERIN, 1928: 825) and a capital crime that had to be punished with the gallows (see von AMIRA, 1922: 87-105; SCHILD, 1985: 197-198; HIS, 1928: 155; WEITZEL, 1909: 13-14).

Some basic characteristics of theft, as revealed in the oldest Germanic legal records, are as follows:

- $\quad$ secret removal; 
- removal from the owner's custody;

- conscious and intentional removal.

In the case of theft, a distinction is made between 'major' and 'minor' theft. In general, the limit is determined by the value of the stolen item, but in certain cases, this property offence is considered a major theft, regardless of the value (cf. BRUNNER/von SCHWERIN, 1928: 828; HAGEMANN, 1975: 3 note 12), such as in the case of certain cattle thefts. ${ }^{5}$ According to old Saxon law, major theft begins at a value of three shillings, which is still taken as the standard centuries later in the Sachsenspiegel.

In Germanic times, theft is generally punishable by fines, and only serious theft and theft in flagranti (German: handhaft) are punishable by the death penalty. In the German-speaking world, it was only at the end of the 11th and the beginning of the 12th century that corporal punishments and punishments ze hût und ze hâr ("to skin and hair") were mentioned with a certain frequency, precisely in the context of the promulgation of the first constitutiones pacis (German Landfrieden). Gradually, an extraordinary system of punishment was established within the Landfrieden, which mainly contained corporal punishment and increasingly rejected the ancient system of fines.

The Landfrieden initially set punishment for minor theft by ze hût und ze hâr and for major theft by loss of the eyes, foot or hand. In contrast, the later Landfrieden established corporal punishment as a penalty for minor theft and the gallows for major theft. This concept is still reflected in German 13th-century legal texts, such as the Sachsenspiegel or Schwabenspiegel.

\section{Theft and its consequences in the lantrecht section of the Sachsenspiegel}

In the lantrecht section of the Sachsenspiegel (ed. Eckhard, 1955), the offence and its consequences are dealt with in various passages:

lantrecht, First Book:

- I 38, 1: thieves are lawless

- I 39: a lawless thief cannot take a cleansing oath and can defend himself from a new charge only by a judgment of God or by a court battle 
- I 55, 2: a gaugraf can judge a thief taken in flagranti in the absence of a competent judge

- I 64: how to prove the guilt of a dead thief

lantrecht, Second Book:

- II 13, 1: how a thief is punished; limited jurisdiction of the village chief (burmeister)

- II 13, 2: exception to the limitation of the jurisdiction of the village chief

- II 13, 6: a fence or accomplice is punished like a thief

- II 26, 2: a man who has become lawless by theft loses his hand when he is found with three and a half pennies of counterfeit money for which he cannot name a guarantor

- II 28 3: how to punish the theft of cut grass or wood depends on the time at which the crime was committed

- II 29: embezzlement is punished, but unlike theft, it does not make the perpetrator lawless

- II 35: definition of theft in flagranti (handhaft)

- II 36, 1-5: how stolen goods can be claimed after being found

- II 37, 1: under what circumstances a find becomes theft

- II 39, 1: how grain theft is punished according to the time at which the crime was committed

- II 64, 2 and 5: indictment for theft with and without the cry of "to the thief!" (German Gerüfte, see LÜCK, 2012)

lantrecht, Third Book:

- III 6, 3: a servant who is robbed while in service is entitled to compensation for the damage by his lord

- III 7, 4: the legal situation of a Jew who is found in possession of sacred objects or other stolen goods

- III 22, 2: the refusal to return borrowed goods is not theft 
- III 45, 9: in the event of an injustice suffered, a person deprived of his rights as a result of theft is not entitled to the usual compensation but only to a mock compensation consisting of two brooms and a pair of scissors

- III 51, 1: wergild rates of domestic and farm animals (among other things as the basis for calculating the limit value for the classification of daytime theft)

- III 89: an object taken by mistake, such as unintentionally traded, is not stolen

In these passages, the author of the Sachsenspiegel deals with the offence and its legal consequences in a wider sense: in fact, not only are the classification of the deed as a more or less serious crime and the form of punishment for the offender treated but also the procedural details relating to the responsibility of the judge, the presentation of the complaint, the burden of proof and, last but not least, the legal status of those found guilty of theft are discussed.

Eike's Sachsenspiegel does not offer a concrete definition of the concept of theft the legal text takes this concept for granted and, consequently, does not bother to define it. The characteristics of theft, such as secret removal, removal from the custody of another person and deliberate and intentional removal, can be deduced ex negativo from information regarding a number of cases that, according to the Sachsenspiegel, should not be considered theft.

Not every theft is the same: depending on the value of the stolen property and the time and circumstances of the crime committed, the Sachsenspiegel distinguishes among major daytime theft, minor daytime theft and theft that occurs within the context of the infringement of some special temporary or local truce or of a truce referring to particular objects.

The difference between major and minor daytime theft is primarily determined by a limit on the value of the stolen goods, which, in the Sachsenspiegel, as in the older Lex Saxonum, is three shillings (see Lex Saxonum 35 and 36, Sachsenspiegel lantrecht II $13,1)$.

In the Sachsenspiegel, major daytime theft is considered an ungerichte, i.e., an offence that cannot be atoned for with a fine, cf. lantrecht II 13,1: Nu vernemet um ungerichte, welk gerichte dâ uber gâ. Den dief sol men hengen. [...] Here, the reference is made not only to the death penalty par excellence but also to the type of execution, by 
the gallows, which was already a typical punishment for major theft in older Germanic legal texts.

As already mentioned, minor daytime theft differs from major daytime theft in the value of the stolen item; minor theft cannot exceed a value of three shillings. However, not only the punishment of but also the procedural approach to the crime differs between minor and major theft. Minor theft carried out in a village belongs to the lower jurisdiction, for which the village chief or Schulthei $\beta$ is responsible: the thief is judged in a kind of fast-track procedure. The jurisdiction of the village chief, moreover, is timelimited: he cannot judge the culprit after a night has passed since the prosecution unless the crime concerns the theft of a large sum or of high-value movable property (see lantrecht II 13, 2).

Particular attention is given in the Sachsenspiegel to the treatment of the crime of theft carried out in the context of the violation of a temporary special truce or a truce referring to specific objects. ${ }^{6}$ In particular, violations of a special nocturnal truce are considered extremely serious. According to the Sachsenspiegel, any theft carried out at night is to be treated as major theft and must be punished with death. This approach is determined not only by the Old Germanic view that a crime carried out in secret is more serious than a manifest crime but also by the fact that property is less protected at night than during the day. In addition, for the thief, the risk of being discovered and arrested is much lower at night, so the threat of the death penalty may also have been thought to pose a deterrent. The impact of the violation of the night truce on the severity of the sentence and/or form of punishment is clarified in the Sachsenspiegel, for example, with regard to the night theft of hay and cut wood (see 4.3 below).

In contrast, a theft concerning sacred objects is considered a violation of a truce referring to specific objects. The Sachsenspiegel explains this condition with the case of a Jew who is found in possession of sacred objects such as goblets, missals and vestments that he bought or pledged: he must be judged as a thief, unless he is able to dispel the suspicion of theft or receiving of stolen goods by referring to the previous owner of the items (see 4.4 below). 


\section{The interrelation of text and images in the representation of the offence of theft in the codices picturati of the Sachsenspiegel}

In the following, I intend to examine the interrelation of the text and images in the codices picturati of the Sachsenspiegel in passages referring to the offence of theft. When assessing the illustrations, researchers should not overlook that the four pictorial manuscripts D (Dresden), H (Heidelberg), O (Oldenburg) and W (Wolfenbüttel), ${ }^{7}$ which were created in the 14th century, are based on a common, unpreserved model, which can explain, despite the many differences in detail, the obvious similarities among them, especially at the compositional level.

4.1. The presentation of the different punishments for major and minor theft lantrecht II 13, 1 (Fig. 1, 2, 3)

In three of the four illustrated manuscripts ${ }^{8}$, the different punishments of major and minor theft are represented in a composition that accompanies the text of the legal institute in lantrecht II 13, 1:

Nû vornemet um ungerichte, welk gerichte dâ uber gâ. Den dief sol men hengen. Schiet aber in deme dorphe des tages eyn dûve, de minner denne drîer schillinge werd is, daz mût die bûrmeister wol richten des selben tagis zu hût unde zu hâre oder mit dren schillingen zu lôsene; sô blîbt jene êrenlôs unde rechtelôs.

In this case, the illustrator depicts the execution of the sentence and not the crime, with the corresponding illustrations in D (Fig. 1) and W (Fig. 2) structured similarly, while the representation in $\mathrm{O}$ (Fig. 3) shows two significant differences. The respective images represent, on the left side, the punishment for major thefts through hanging on the gallows. The gallows depicted is a type that had been used since ancient times, in which the transverse beam rests on two forks (cf. SCHILD, 1985: 198 and 216; von AMIRA, 1922: 91-93). It is striking that in $\mathrm{D}$, the construction of the gallows is evidently much more primitive and antiquated than that in the other two manuscripts. The thief has, according to ancient customs, his hands tied behind his back and is blindfolded; he is fully clothed. ${ }^{9}$ The respective right side of the images contains, in 
addition to the representation of the punishment for minor thefts, a clear reference to the competent jurisdiction. The village chief, indicated by the straw hat he wears, serves as a judge. In accordance with his function, he is portrayed sitting; he indicates the henchman to the thief in front of him, highlighting, at the same time, his competence in the legal matter. In D and $\mathrm{W}$, the henchman holds scissors and obviously threatens the thief with the common penalty zu hût und zu hâr, the execution of which is represented in the sequence of images that follow - albeit with reference to another crime - while the illustrations of the consequences of theft shown in D and $\mathrm{W}$ also depict the possibility of replacing the bodily punishment: the perpetrator evades the threatened penalty by paying a fine on the payment board drawn between the thief and the village chief.

The differences in the representation of minor theft in the corresponding illustrations of manuscript $\mathrm{O}$ are evident (Fig. 3). Here, instead of scissors, the henchman holds a sword in his hand, and the thief does not pay a fine but takes a cleansing oath on a reliquary. In the first case, we are obviously faced with an inaccuracy: the executioner's sword belongs to the high jurisdiction and cannot be reconciled with the representation of the village chief as a judge. In the case of the second difference, which until now has also been judged by critics to be an inaccuracy (see von AMIRA, 1925: 348; SCHEELE, 1992: 199), we are, in my opinion, confronted with an intentional variant of the illustrator that may have been prompted by other passages of the Sachsenspiegel: I am referring in particular to the rule that states under what circumstances an accusation of embezzlement or theft can be dismissed through an oath of purification as a proof of innocence, that is, when it cannot be proven that the corresponding movable property is actually in the possession of the accused. The right side of the image in $\mathrm{O}$ thus integrates the text and connects it visually with a textual reference related to the evidentiary procedure in case of a theft charge reported in another passage of the Sachsenspiegel.

In all three illustrations, two essential circumstances dealt with in the text are not considered: there is neither a visual implementation of the time limit for the competence of the village chief nor of the consequence of the loss of rights and honor by the convicted thief. Nonetheless, the illustrations offer, with the depiction of the henchman available to the village chief as an executor of the judgment, an important addition to 
the text, namely, that the village chief in his function as a judge has an enforcement body at his disposal.

\subsection{Theft against a servant - lantrecht III 6, 3 (Fig. 4, 5, 6, 7)}

Of particular interest is a provision of the Sachsenspiegel that sets out the situation of a servant who becomes a victim of a theft or a robbery while in the service of his lord. If a servant while in the service of his lord is robbed of his horse or another good by no fault of his own, the loss will have to be compensated by the lord ${ }^{10}$, who in return shall be given the right to act as a plaintiff. This is a rule for which, as far as I know, there is no equivalent in the oldest legal Germanic sources.

Wirt aber yme sîn perd oder ander sîn gût dûfleke oder roufleke genomen in des herren dienste, âne des knechtes schult, daz mût ime die herre gelden; dâ vore mût men ouch deme herren antworden, ob her dâ uphe claget.

This provision is illustrated in all four manuscripts. Not only is the legal institution itself depicted but the detailed presentation of the act itself is also found. The illustrations of the consequences of the nocturnal theft of a horse in H (Fig. 4), D (Fig. 5) and W (Fig. 6) represent the left part of the pictures, and O (Fig. 7) represents the right part, while in the text, there is generally a discussion of a theft or robbery without referring to the time at which the crime occurred. The clear description of the act as a theft during the night serves here to underline that the robbed servant is without fault. The attributes of a nocturnal theft are accentuated differently by the illustrators: all four representations have in common that the servant resting unclothed under a blanket is sleeping outside the stable; in $\mathrm{O}$, a moon and two stars are depicted above the sleeping servant's head, symbolically referring to nighttime. The horse is pulled out of the stable by the thief by the reins, with the illustrator of $\mathrm{H}$ stressing that the thief has penetrated an initially locked building, as seen by the fact that he is shown holding the door open with his left hand.

Since the illustrators have already represented the consequences for the convicted thief elsewhere, they focus here on depicting the crime itself and the legal consequences for the victim of the theft in a special case, i.e., the relationship between a servant and 
his lord. As it is difficult to protect oneself from theft at night, the innocence of the servant, which is the necessary condition for compensation to take place, seems to be obvious to the illustrators. ${ }^{11}$ The severity of the penalty for nocturnal theft, as attested elsewhere in the Sachsenspiegel, is, among other things, motivated by the fact that it is usually not easy to find the thief or recover the stolen goods, which certainly had to be more difficult for a servant than for his master. The transfer of the right of action to the lord also improves the legal situation of the plaintiff: while the servant has only a limited legal capacity ${ }^{12}$, the lord, due to his social position, has access to major legal means.

The reimbursement of the damage by the lord is shown in the right parts of $D, H$ and $\mathrm{W}$ and in the left part of $\mathrm{O}$. The lord, marked by his special clothing and headdress counts the coins and places them in the servant's extended robe. The illustrator of $O$ refers specifically to the value of the stolen goods by placing four coins above the head of the horse. ${ }^{13}$ The passage of the right of indictment to the lord is not depicted.

In assessing the interrelationship of the text and images in the case of this legal institution, it can be said, in addition to the considerations described above, that the pictorial implementation, through the representation of a clear nocturnal theft, complements and enriches the text by exemplifying the innocence of the stolen servant, which remains vague in the text. Thanks to the illustration of an exemplary case, any legal uncertainties about the 'guilty' or 'culpable' behavior of the servant can be removed: if he is the victim of a theft during the night, then he is clearly entitled to compensation by his master, which - as the depiction of the sequence of scenes in the corresponding picture slips suggests - must be paid immediately.

4.3. The theft of hay and cut wood - lantrecht II 28, 3 (Fig. 8, 9, 10)

The theft of cut wood and hay is treated in the Sachsenspiegel as a particularly qualified theft if the thief commits his crime at night.

Swer nachtes gehowen gras oder gehowen holt stelet, daz sol men richten mit der weden. Stelet her 'is' des tages, iz gât zu hût und zu hâr. 
Those who appropriate hay or wood during the night that has already been cut must be brought to the gallows with a wicker rope; the same theft, if committed during the day, results only in corporal punishment ( $z u$ hut und zu hâr). It is noteworthy in this context that no value limit is stated for the theft: nocturnal theft of wood and hay is punished with shameful death by hanging, even if its value is low.

The illustrators of manuscripts D (Fig. 8), O (Fig. 9) and W (Fig. 10) ${ }^{14}$ specify the conflicting facts already presented in the text through a corresponding bipartite composition in which one side depicts the punishment of daytime theft and the opposite side that of nocturnal theft. The moment of the commission of the crime is shown at the upper edge, in the case of daytime theft by a sun and in the case of a nocturnal offence by a moon. The reference to the theft of wood and hay is highlighted in particular in D and $\mathrm{W}$, where, on the left side of the image, two bundles of cut grass and wood lie at the thief's feet, while the extension to the right of the scene is used to represent other bundles of wood and cut grass. In $\mathrm{O}$, by contrast, the screaming thief, who is led to the gallows by the executioner with a willow rope wrapped around his neck, still carries in his hand the stolen goods in the form of a bundle of wood.

The depiction of the punishment of daytime theft by zu hût und $z u$ hâr, a public and humiliating punishment, shows the almost completely undressed thief standing with his arms tied to the pile. The executioner beats the offender with a rod in his left hand while, with the scissors in his right hand, he cuts off the thief's hair.

In the illustration of the punishment of nocturnal theft with a weden (a rope made of willow rods), the depiction of the gallows is dispensed with ${ }^{15}$, but the perpetrator already has a noose around his neck by which the henchman leads him to the place of execution. Notably, all three illustrators characterize theft as a crime in flagranti by depicting stolen goods, as particularly noticeable in $\mathrm{O}$.

The interrelationship of the text and image in the case of this legal institution allow the text to be implemented iconographically such that the pictorial representation can replace the text and thus be understandable even for an illiterate audience: the statement that nocturnal theft of cut wood and hay is punished by the gallows whereas daytime theft incurs a public, dishonorable corporal punishment is completely translated into images, whereby the death penalty is represented by hanging not by the gallows but - as pars pro toto - by a rope. The representation of stolen goods clearly references the 
fact that the offender, in the case of nocturnal theft, has been taken in flagranti, thus reminding the audience of the fact that the death penalty can only be carried out if there is clear evidence - a detail that clearly extends beyond the information provided in the legal text.

4.4. Stolen sacred objects or other stolen goods in the custody of a Jew - lantrecht III 7, 4 (Fig. 14, 15, 16, 17)

As part of the presentation of the laws concerning Jews, the Sachsenspiegel also deals with the legal situation of a Jew who is found in possession of stolen sacred objects or other stolen goods.

Koupht die jode oder nymt her zu wedde kelkhe oder bûche oder gerwe, dâ her nichênen weren ane hât, vint men iz binnen sînen weren, men richtet uber ine alse uber eynen dief.

A Jew who buys or pledges stolen sacred objects for which he has no guarantor must be judged as a thief when these items are found in his possession.

The case of the theft or reception of so-called res sacrae is considered a special theft offence that, by the act of the desacralization of objects consecrated to worship, leads to an infringement of a truce referring to specific objects. ${ }^{16}$ Knowledge that, in this case, such property must necessarily be stolen goods and not legally purchased items can be taken for granted and leads to a presumption of guilt for those who buy or pledge these goods. Only by being able to cite a guarantor can the accused prove his innocence.

The situation presented in lantrecht III 7, 4, and the prosecution and, consequently, execution of the culprit are translated into images in all four codices picturati of the Sachsenspiegel. Common to all four illustrations is the representation of the trial with the prosecution before a judge and the indication of the stolen or illegally received goods - in D (fig. 14), $\mathrm{H}$ (fig. 15) and $\mathrm{W}$ (fig. 16) on the left and in $\mathrm{O}$ (fig. 17) on the right - as well as the illustration of the culprit's punishment by death on the gallows on the opposite side.

The judge is identified as a count by his headdress (in the case of $\mathrm{O}$, also by a sword) - it is, therefore, a case of high jurisdiction. The prosecutor indicates the sacral 
objects, a chalice and a missal, with a clear pointing gesture; the vestments mentioned in the text are not depicted. The accused, made recognizable as Jewish by the fact that he is wearing a pointed hat, is standing with his hands tied in front of the judge. The chaining of the accused is evident in $\mathrm{H}$ and $\mathrm{O}$, while it is only mentioned but nonetheless deducible from the position of his crossed wrists in D and $\mathrm{W}$. The fact that the thief is brought before the judge as if he had been caught red-handed explains why, if he is unable to indicate any guarantor for the sacred objects in his possession, he will have to be treated as a fencer (and therefore as a criminal equated with a thief). The movement of the judge's hand can be interpreted as an order, i.e., the invitation to the executioner to carry out the death penalty. The execution of the sentence is depicted in the other part of the image: the henchman is about to hang the perpetrator; to this end, he pulls the rope, which is already around the criminal's neck, with both hands over the crossbeam resting on two forked branches. In D, O and W, the Jewish man's hands are tied behind his back, which was considered particularly insulting. Also notable is the depiction of the hanged man in $\mathrm{O}$, with a bare torso and blindfolded eyes, which indicates older legal customs (cf. SCHEELE, 1992: 204-205; von AMIRA, 1925: 466467).

In addition to the detailed translation of the legal text into images, the illustrations here offer further information. On the one hand, it is stated unequivocally that, in the case of the discovery of res sacrae in the custody of a Jewish trader and pawnbroker, it is clear from the outset that it must be illegal, even if the text correctly, at least in theory, postulates the possible existence of a guarantor. On the other hand, it is made clear through the depiction of the judge that this is a high court case. In addition, it is recalled, figuratively, that serious theft and 'equivalent' crimes, such as receiving stolen goods, require death on the gallows as punishment. The pictorial medium is thus used to further clarify and develop the legal situation dealt with in the text.

\section{Conclusive remarks}

In this article, after a general presentation of the crime of theft in the Sachsenspiegel, the relationship between the text and images in the four codices picturati of this Middle Low German legal book is examined in the context of some 
passages directly related to theft and its punishment to demonstrate that the illustrations in these manuscripts can, in certain cases, contribute to a better understanding of legal institutions in the German Middle Ages.

The evaluation of the illustrations allows us to confirm that the four manuscripts from the 14th century, D (Dresden), H (Heidelberg), O (Oldenburg) and $\mathrm{W}$ (Wolfenbüttel), can be traced back to an unpreserved common model, which explains their obvious similarities, especially in terms of their pictorial composition. For this reason, the differences that have been highlighted appear even more significant. Some of these differences, in fact, clearly reflect different, more or less ancient legal habits. In all the cases analyzed, it was possible to show that both the media considered - text and images - bear comparable weight with regard to their communicative function: the images are never subordinated to the text, for example, as a decorative addition, but rather, the unity of images and text enhances the basic conception of representing the offence of theft in these manuscripts. The images not only convert the text in detail into a corresponding visual composition to make it more understandable but also integrate and comment on the text as often as it appears necessary to the illustrator. As has been noted, the illustrations, in certain cases, also provide additional information: thus, in the case of lantrecht II 13, 1, the figurative representation of the henchman shows that the village chief, in his role as judge, has at his disposal an executive body (see above, 4.1); in the case of lantrecht II 6, 3, any doubts about the meaning of 'innocent' or 'guilty' behavior on the part of the robbed servant are dispelled (see above, 4.2); in the case of lantrecht II, 28, 3, the presentation of the stolen goods in the case of nocturnal theft clearly indicates that the thief has been apprehended in flagranti and thus highlights the fact that the death penalty can only be carried out if there is clear evidence (see above, 4.3). It was also possible to note that in certain cases, the text is implemented in detail, even in complex situations, in such a way that the pictorial representation can replace the text and thus also be comprehensible to an illiterate audience (see above, 4.3.). Last but not least, it has been shown that the pictorial medium can be used to clarify and further develop the legal situation dealt with in the text, for example, when lantrecht II 7,4 visually recalls that death on the gallows is based on serious theft and 'equivalent crimes such as fencing (see above, 4.4.). 
In general, the illustrations in the codices picturati of the Sachsenspiegel can significantly contribute to a better understanding of medieval legal concepts in the area of theft offences and their punishment. In almost all the examples examined, the illustrators select scenes that are suitable for concretizing or exemplifying statements of the legal text, thereby offering interpretative aid for the respective legal text.

Regarding the function of the images used in relation to the legal text, the investigation has shown that the three main types of functions (see also SCHMIDTWIEGAND, 1988: 376-377; HÜPPER, 1992: 243-247) that can be identified are the following: the image as a clarification of a legal statement, possibly with the representation of alternative variants of a circumstance; the image as a concretization of a legal concept; and the image as an exemplification of the legal consequences of a crime.

Although it has been possible to demonstrate that the illustrations generally contribute to a better understanding of the legal concepts discussed in the text, this does not mean that the text cannot exist without the images. On the contrary, the images are generally not simply a substitute for the text; they are text-dependent to varying degrees (cf. PERRIN - ROCKMANN, 2011: 54) but do more than just reproduce the contents of the relative text (cf. SCHMIDT-WIEGAND, 1986: 11). By accentuating and exemplifying the written word, the images not only contribute to a deeper understanding of the illustrated text but also draw the recipient's attention time and again to central legal institutions. The fact that the illustrators, in the context of the representation of crimes against property, focus in particular on the criminal consequences related to the violation of a temporal truce can be seen as an indication that this legal concept in relation to the qualification of major theft played an important role not only in the early Germanic legal tradition but also during the time of the creation of the four codices picturati of the Sachsenspiegel, thus evidencing an important constant in GermanicGerman legal thought. 


\section{Bibliography}

A. Manuscripts and reproductions in facsimile

A.1. Dresden, Sächsische Landes- und Universitätsbibliothek, Mscr.Dresd.M.32

Die Dresdener Bilderhandschrift des Sachsenspiegels, ed. K. von AMIRA, vol. I: faksimile, Leipzig, Hiersemann, 1902 (reprint Osnabrück: Otto Zeller, 1968), digital version: http://digi.ub.uni-heidelberg.de/diglit/amira1902bd1/0001

Eike von Repgow. ,Sachsenspiegel'. Die Dresdner Bilderhandschrift Mscr. Dresd. $M$ 32. Vollständige Faksimile-Ausgabe im Originalformat der Handschrift aus der Sächsischen Landesbibliothek - Staats- und Universitätsbibliothek Dresden, I: Faksimile, II: Textband, ed. H. Lück unter Mitarbeit von T. Haffner, M. Perrin, J. Weinert (Codices selecti phototypice impressi 107), Graz: Akademische Druck- und Verlagsanstalt, 2006.

A.2. Heidelberg, Universitätsbibliothek Cod. Pal. Germ 164

Digital version: http://digi.ub.uni-heidelberg.de/diglit/cpg164

Eike von Repgow: Sachsenspiegel. Die Heidelberger Bilderhandschrift Cod. Pal. Germ. 164. Vollständige Faksimile-Ausgabe im Originalformat der Handschrift aus der Universitätsbibliothek Heidelberg, ed. G. Kocher - D. Munzel-Everling (Codices Selecti 115), Graz: Akademische Druck- und Verlagsanstalt, 2009/2010.

A.3. Oldenburg, Landesbibliothek, CIM I 410 (olim Oldenburg, Großherzogliche Privatbibliothek A, 1,1)

Digital version: http://digital.lb-oldenburg.de/ssp/nav/classification/137692

Der Oldenburger Sachsenspiegel. Vollständige Faksimile-Ausgabe im Originalformat des Codex picturatus Oldenburgensis CIM I 410 der Landesbibliothek Oldenburg, ed. R. Schmidt-Wiegand im Auftrag der Niedersächsischen Sparkassenstiftung, Graz: Akademische Druck- und Verlagsanstalt, 1995. 
A.4. Wolfenbüttel, Herzog August Bibliothek cod. 3.1.Aug fol.

Digital version: http://diglib.hab.de/mss/3-1-aug-2f

Eike von Repgow Sachsenspiegel. Die Wolfenbütteler Bilderhandschrift Cod. Guelf. 3.1 Aug. $2^{\circ}$, ed. R. Schmidt-Wiegand, Faksimile-Band, Textband und Kommentarband, Berlin: Akademie-Verlag, 1993.

B. Other primary sources

Leges Burgundionum, ed. L. R. von Salis, Hannover: Hahn'sche Buchhandlung, 1892 (Lex Burgundionum e Lex Romana Burgundionum).

Leges Saxonum und Lex Thuringorum, ed. C. Freiherr von Schwerin, Hannover Leipzig: Hahn'sche Buchhandlung, 1918.

Sachsenspiegel Landrecht, ed. K. A. Eckhart, Hannover: Hahn'sche Buchhandlung, 1955.

C. Studies

Amira, K. von, Die germanischen Todesstrafen: Untersuchungen zur Rechts- und Religionsgeschichte (Abhandlungen der Bayerischen Akademie der Wissenschaften, Philosophisch-Philologische und Historische Klasse, Bd. 31,3), München,: Verlag der Bayerischen Akademie der Wissenschaften, 1922.

Amira, K. von, Die Dresdener Bilderhandschrift des Sachsenspiegels. Vol. 2: Erläuterungen Teil I, Leipzig: Verlag Karl W. Hiersemann, 1925.

Becker, H.-J., res sacrae, in Handwörterbuch zur deutschen Rechtsgeschichte, ed. A. Erler - E. Kaufmann, vol. IV, Berlin: Erich Schmidt Verlag, 1990, col. 925-926.

Brunner, H., Deutsche Rechtsgeschichte, Vol. II, zweite Auflage bearbeitet von C. Freiherrn von Schwerin, München - Leipzig: Duncker \& Humblot, 1928. 
Engels, J. I., Zum historischen Quellenwert von Bildern. Das Beispiel des Sachsenspiegels, in Funktion und Form. Quellen- und Methodenprobleme der mittelalterlichen Rechtsgeschichte, ed. K. Kroeschell - A. Cordes, Berlin: Duncker \& Humblot,1996, p. 153-184.

Friese, V., Das Strafrecht des Sachsenspiegels, Breslau: Verlag von M. \& H. Marcus, 1898.

Hagemann, H.-R., Vom Diebstahl im alten Recht, in Festschrift für Hermann Krause, ed. S. Gagnér - H. Schlosser - W. Wiegand, Köln - Wien: Böhlau Verlag, 1975, p. $1-20$.

Hayduk, H. S., Rechtsidee und Bild: zur Funktion und Ikonografie der Bilder in Rechtsbüchern vom 9. Bis zum 16. Jahrhundert, Wiesbaden: Reichert, 2011.

Hirschberg, R., Der Vermögensbegriff im Strafrecht: Versuch eines Systems der Vermögensdelikte, Berlin: Springer, 1934.

His, R., Geschichte des deutschen Strafrechts bis zur Karolina, München - Berlin: Oldenbourg Verlag, 1928.

Hüpper, D., Funktionstypen der Bilder in den Codices picturati des Sachsenspiegels, in Pragmatische Schriftlichkeit im Mittelalter. Erscheinungsformen und Entwicklungsstufen (Akten des Internationalen Kolloquiums, 17. - 19. Mai 1989), ed. H. Keller - K. Grubmüller - N. Staubach, München: Wilhelm Fink Verlag, 1992, p. 231-249.

Hüpper, D., Illustrated Manuscripts ft he Sachsenspiegel, in Jahrbuch der Oswald von Wolkenstein Gesellschaft 11 (1999), p. 113-142.

Knollmann, W., Die bunten Bilder des Oldenburger Sachsenspiegels, Oldenburg: Isensee Verlag, 1998.

Kocher, G., Sachsenspiegel, Institutiones, Digesten, Codex - Zum Aussagewert mittelalterlicher Rechtsillustrationen, in Forschungen zur Rechtsarchäologie und Rechtlicher Volkskunde, ed. L. Carlen, Zürich: Schulthess Polygraphischer Verlag, 1981, p. 5-34. 
Lück, H., Gerüfte, in Handwörterbuch zur deutschen Rechtsgeschichte. 2. Aufl., ed. A. Cordes - H. Lück - D. Werkmüller, vol. II. Berlin: Erich Schmidt Verlag, 2012, col. 259-264.

Manuwald, H., Narrative Bilder in Rechtshandschriften. Zu den Codices picturati des Sachsenspiegels, in AusBILDung des Rechts, ed. K. Böse - S. Wittekind, Frankfurt: Peter Lang, 2009, p. 136-165.

Manuwald, H., Pictorial narrative in legal manuscripts? The Sachsenspiegel manuscript in Wolfenbüttel, in Word \& Image: A Journal of verbal/Visual Enquiry 23/3 (2007), p. 275-289.

Margadant, G. F. The illustrations of the Sachsenspiegel. A medieval German law book, Austin/Texas: The University of Texas School of Law, 2000.

Ogris, W., Gewere, in Handwörterbuch zur deutschen Rechtsgeschichte, 2. Aufl., ed. A. Cordes - H. Lück - D. Werkmüller, vol. II, Berlin: Erich Schmidt Verlag, 2009, col. 347-352.

Ott, N. H., Vorläufige Bemerkungen zur >Sachsenspiegel`-Ikonographie, in TextBild - Interpretation. Untersuchungen zu den Bilderhandschriften des Sachsenspiegels, ed. R. Schmidt-Wiegand, München: Wilhelm Fink, 1986, vol. I. Textband, p. 33-43, VOL. II Tafelband, Tafel XXII-XXX.

Perrin, M. - Rockmann, M., Zur Ikonographie der Dresdner Bilderhandschrift des Sachsenspiegels. Ein Erfahrungsbericht zur Methode aus der Praxis der Bildanalyse, in Eike von Repgow, Sachsenspiegel. Die Dresdner Bilderhandschrift Mscr. Dresd M 32. Vollständige Faksimile-Ausgabe im Originalformat der Handschrift aus der Sächsischen Landesbibliothek - Staats- und Universitätsbibliothek Dresden. Aufsätze und Untersuchungen, ed. H. Lück, Graz: Akademische Druck- und Verlagsanstalt, 2011, p. 47-54.

Scheele, F., Gedanken zur Herstellung und Gestaltung der Miniaturen des Dresdner Codex picturatus des Sachsenspiegels, in Eike von Repgow, Sachsenspiegel. Die Dresdner Bilderhandschrift Mscr. Dresd M 32. Vollständige faksimile-Ausgabe im Originalformat der Handschrift aus der Sächsischen Landesbibliothek - Staats- und Universitätsbibliothek Dresden. Aufsätze und Untersuchungen, ed. H. Lück, Graz: Akademische Druck- und Verlagsanstalt, 2011, p. 61-77. 
Scheele, F., Di sal man alle radebrechen. Todeswürdige Delikte und ihre Bestrafung in den Codices picturati des Sachsenspiegels, vol. I: Textband, vol. II: Tafelband, Oldenburg: Isensee, 1992.

Schild, W., Alte Gerichtsbarkeit. Vom Gottesurteil bis zum Beginn der modernen Rechtsprechung, 2. Auflage, München: Callwey Verlag, 1985.

Schmidt-Wiegand, R., Text und Bild in den Codices picturati des \Sachsenspiegels‘. Überlegungen zur Funktion der Illustration, in Text - Bild Interpretation. Untersuchungen zu den Bilderhandschriften des Sachsenspiegels, ed. R. Schmidt-Wiegand, München: Wilhelm Fink, 1986, vol. I. Textband, p. 11-31, vol. II. Tafelband Tafel I-XXI.

Schmidt-Wiegand, R., Die Bilderhandschriften des Sachsenspiegels als Zeugen pragmatischer Schriftlichkeit, in Frühmittelalterliche Studien 22 (1988), p. 357-387.

Schmidt-Wiegand, R., Die Bilderhandschriften des Sachsenspiegels im Vergleich, in Gott ist selber Recht. Die vier Bilderhandschriften des Sachsenspiegels. Oldenburg, Heidelberg, Wolfenbüttel, Dresden. Katalog der Ausstellung in der Schatzkammer der Bibliotheca Augusta vom 12. Februar bis 11. März 1992, Wolfenbüttel: Herzog August Bibliothek, 1992, p. 9-30.

Schmidt-Wiegand, R. - Hüpper, D. (eds.). Der Sachsenspiegel als Buch, Frankfurt am Main - Bern - New York - Paris: Peter Lang, 1991.

Weitzel, K., Diebstahl und Frevel und ihre Beziehung zu Hoch- und Niedergerichtsbarkeit in den alamannischen Rechtsquellen des Mittelalters, Borna Leipzig: Buchdruckerei Robert Noske, 1909.

Zillgen, I., Geschichte und Sinn des schweren Diebstahls, Berlin: Verlag Dr. Emil Ebering, 1940. 


\section{Images}

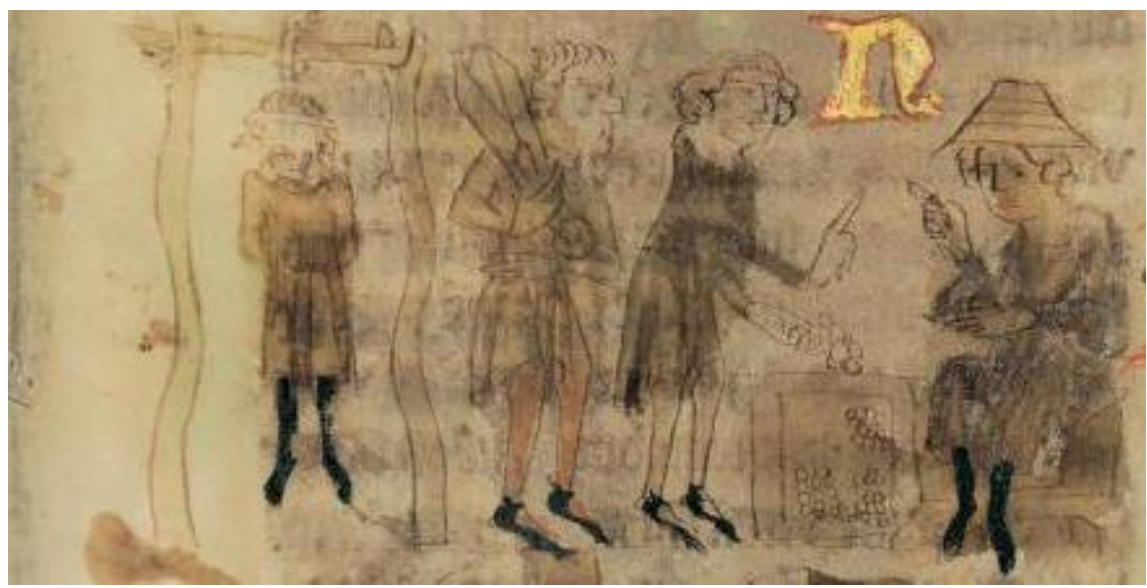

Fig. 1 - MS. D fol. 25 r, picture strip no. 3

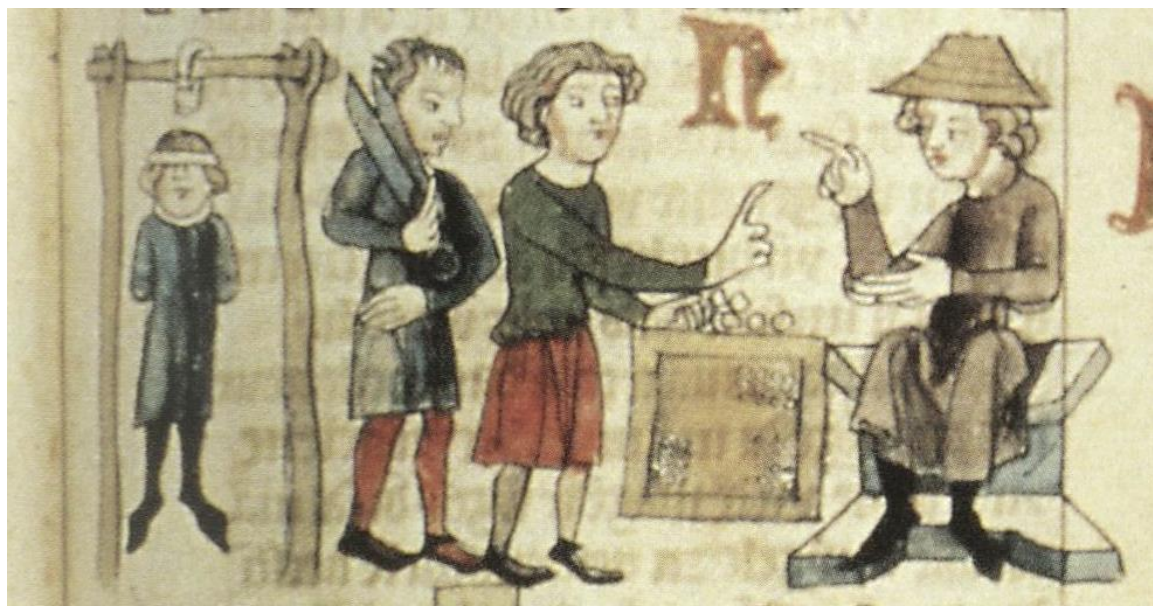

Fig. 2 - MS. W fol. 29 r, picture strip no. 3 


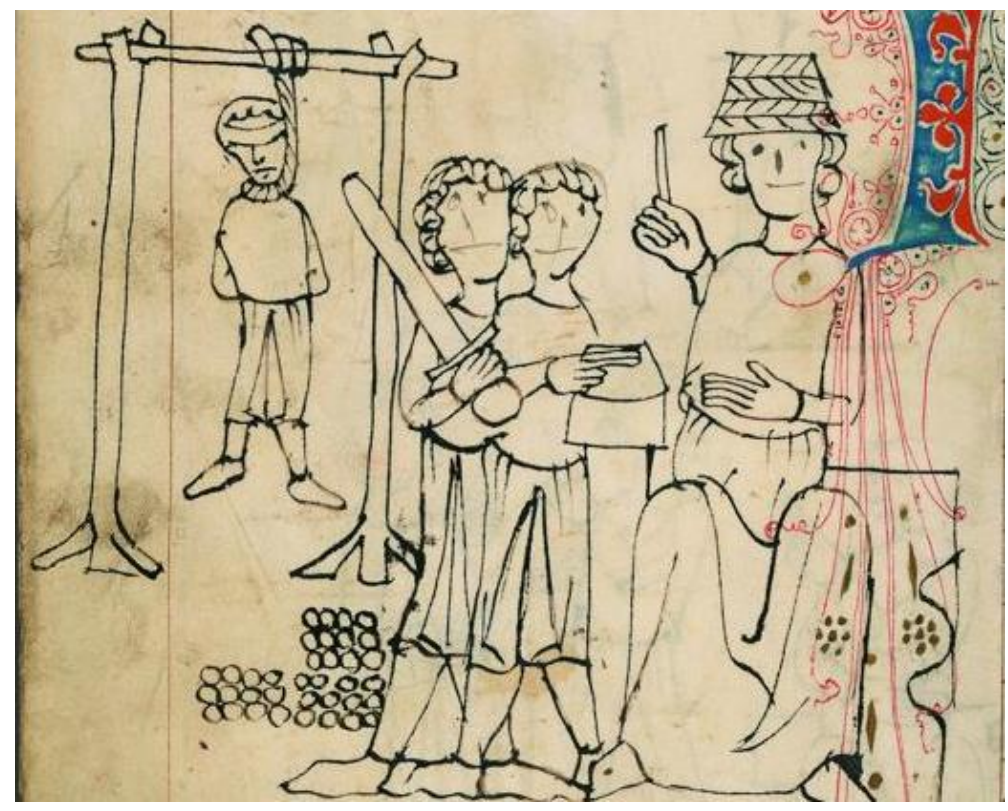

Fig. 3 - MS. O fol. 43 v, picture strip no. 2

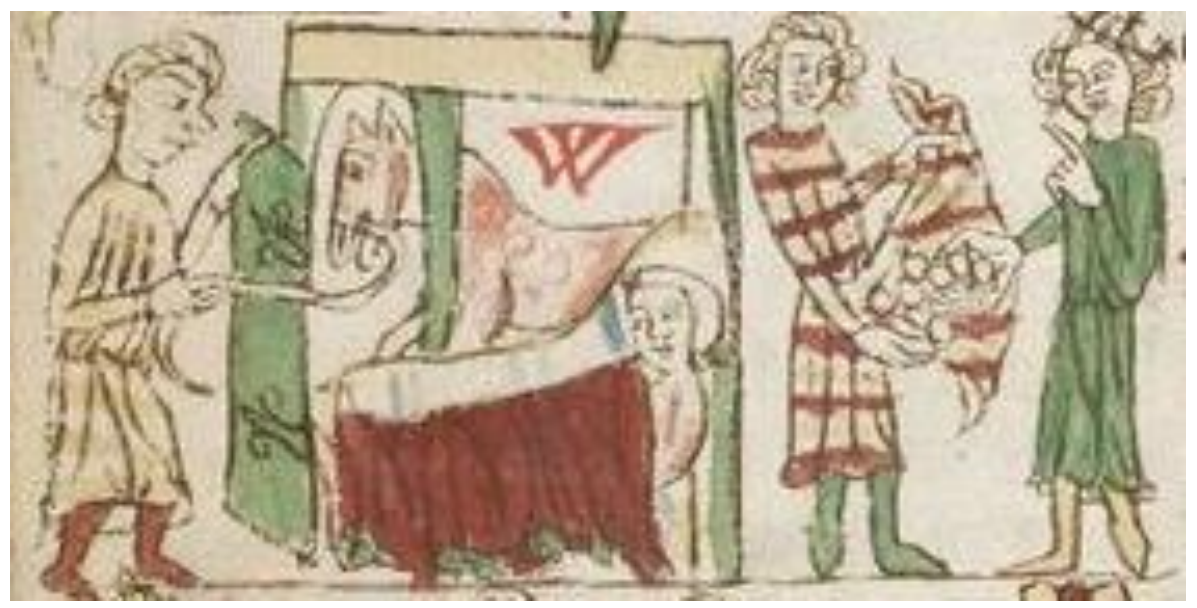

Fig. 4 - MS. H fol. 13v, picture strip no. 2

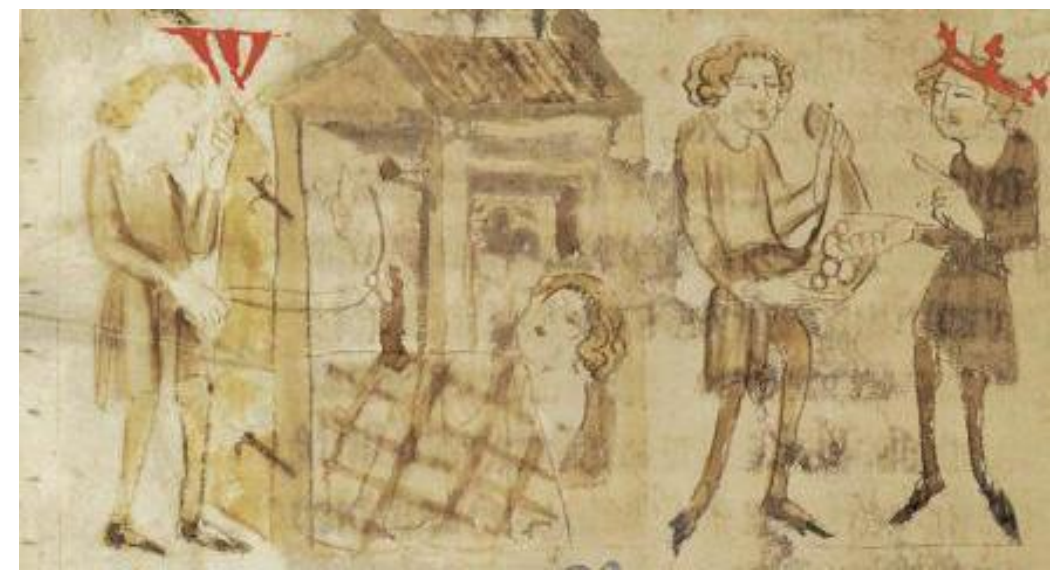

Fig. 5 - MS. D fol. 37v, picture strip no. 2 


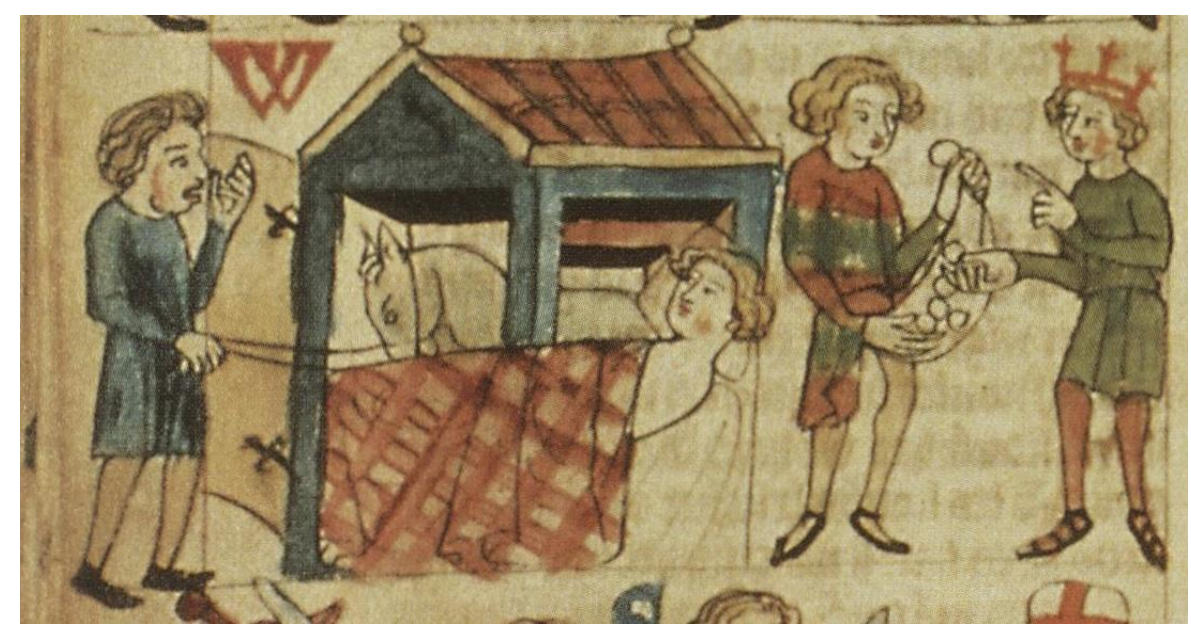

Fig. 6 - MS. W fol $43 \mathrm{v}$, picture strip no. 2

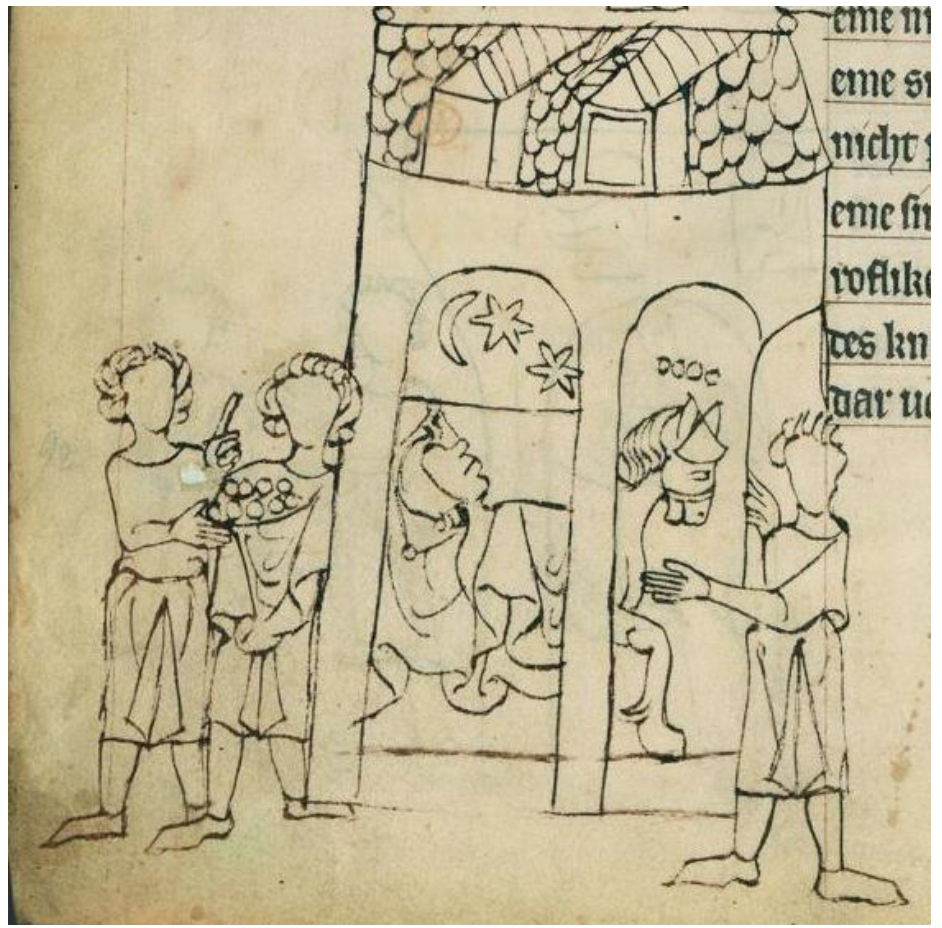

Fig. 7 - MS. O fol. $65 \mathrm{v}$, picture strip no. 3 


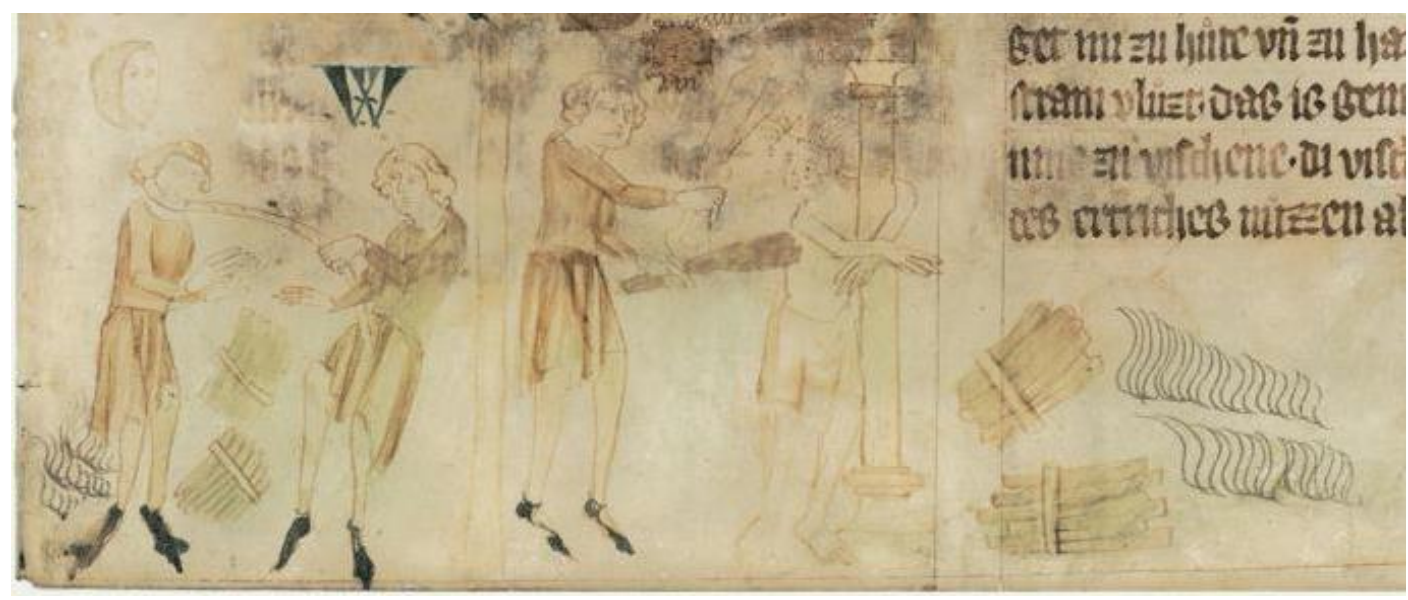

Fig. 8 - MS. D fol. 29r, picture strip no. 5

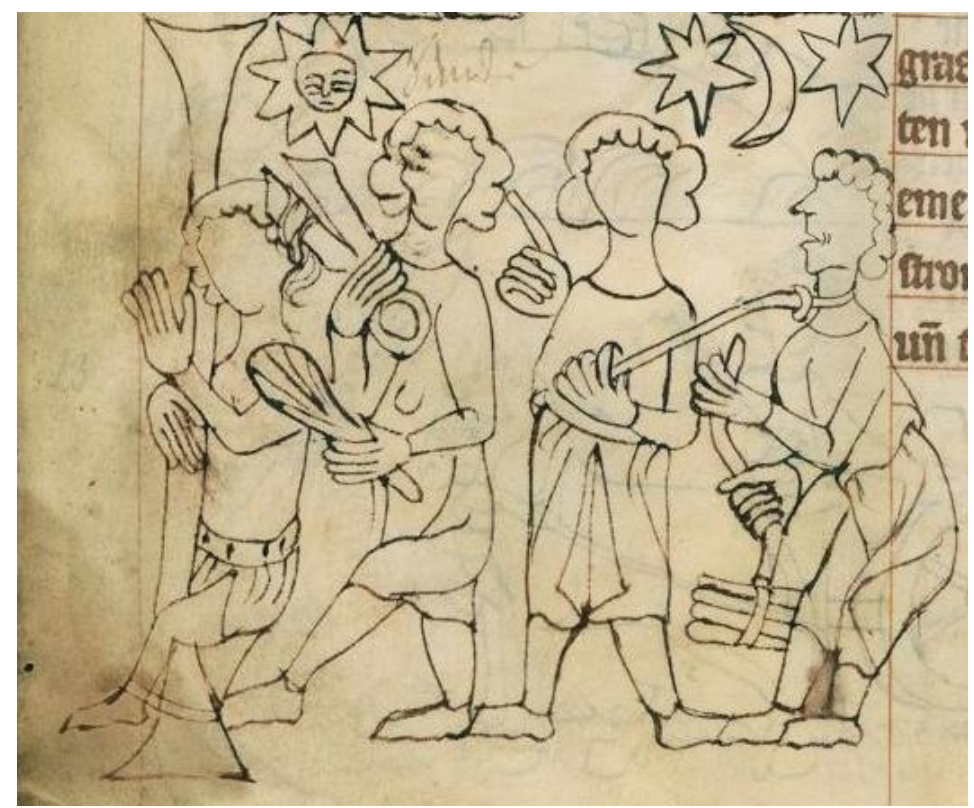

Fig. 9 - MS. O fol. 49v, picture strip no. 3

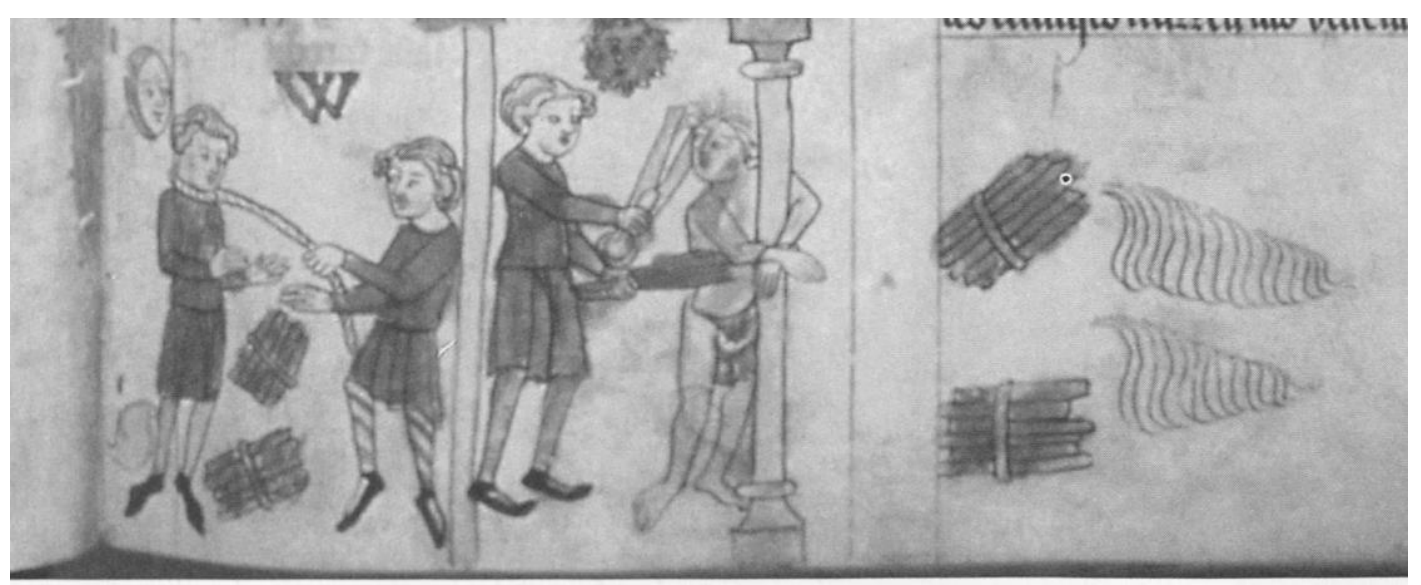

Fig. 10 - MS. W fol. 33r, picture strip no. 5 


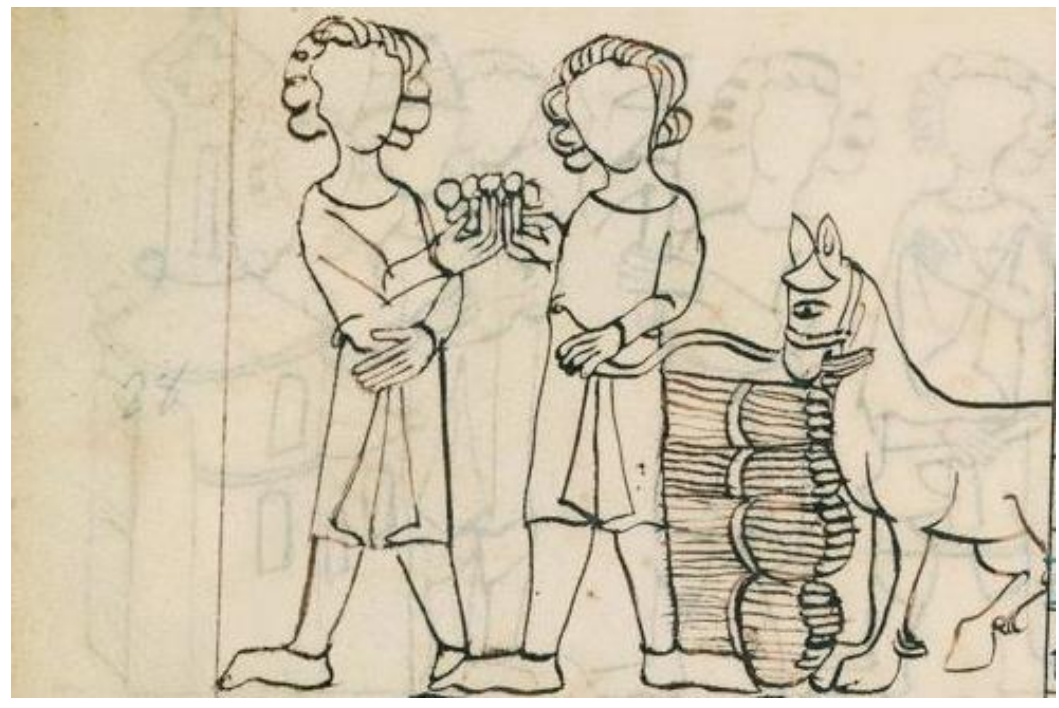

Fig. 11 - MS. O 52v, picture strip no. 1

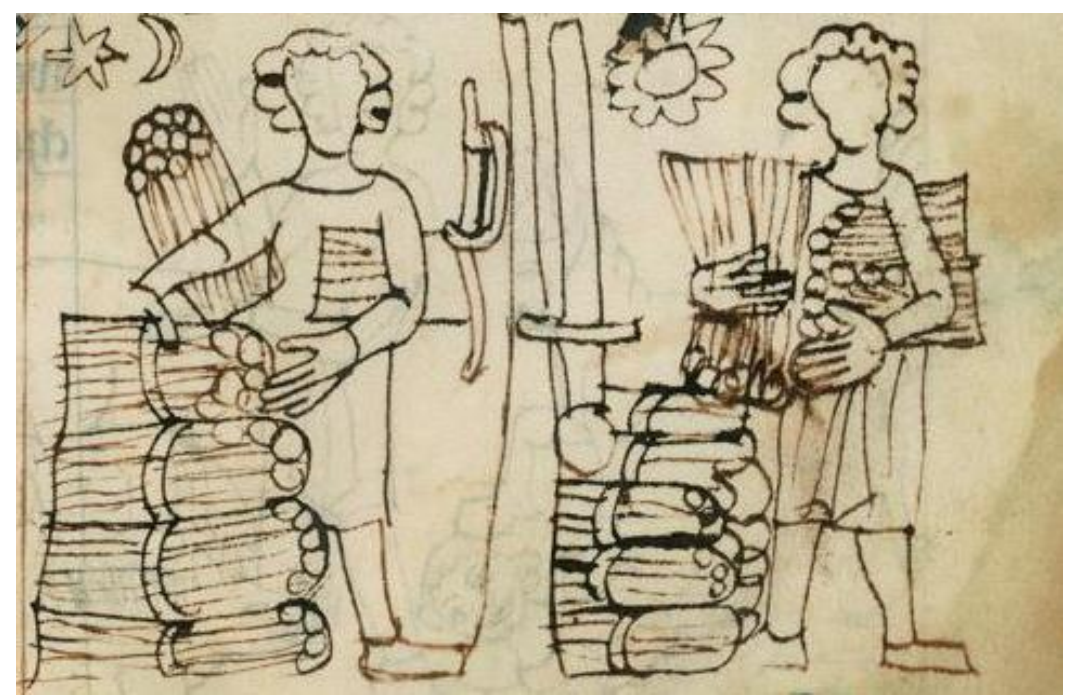

Fig. 12 - MS. O fol. 52r, picture strip no. 4

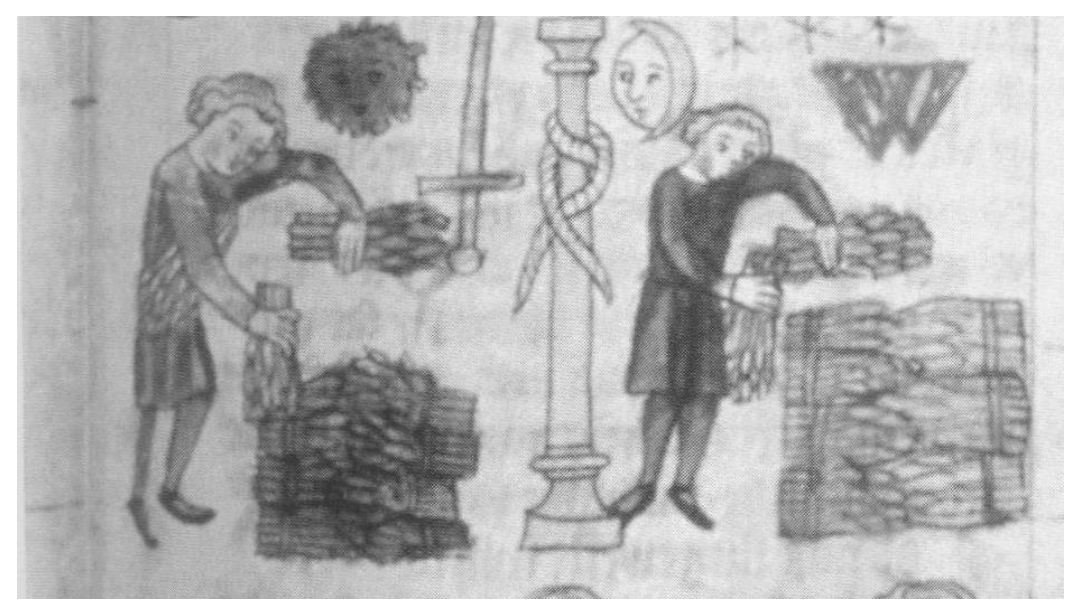

Fig. 13 - MS. W fol. 35r, picture strip no.4 


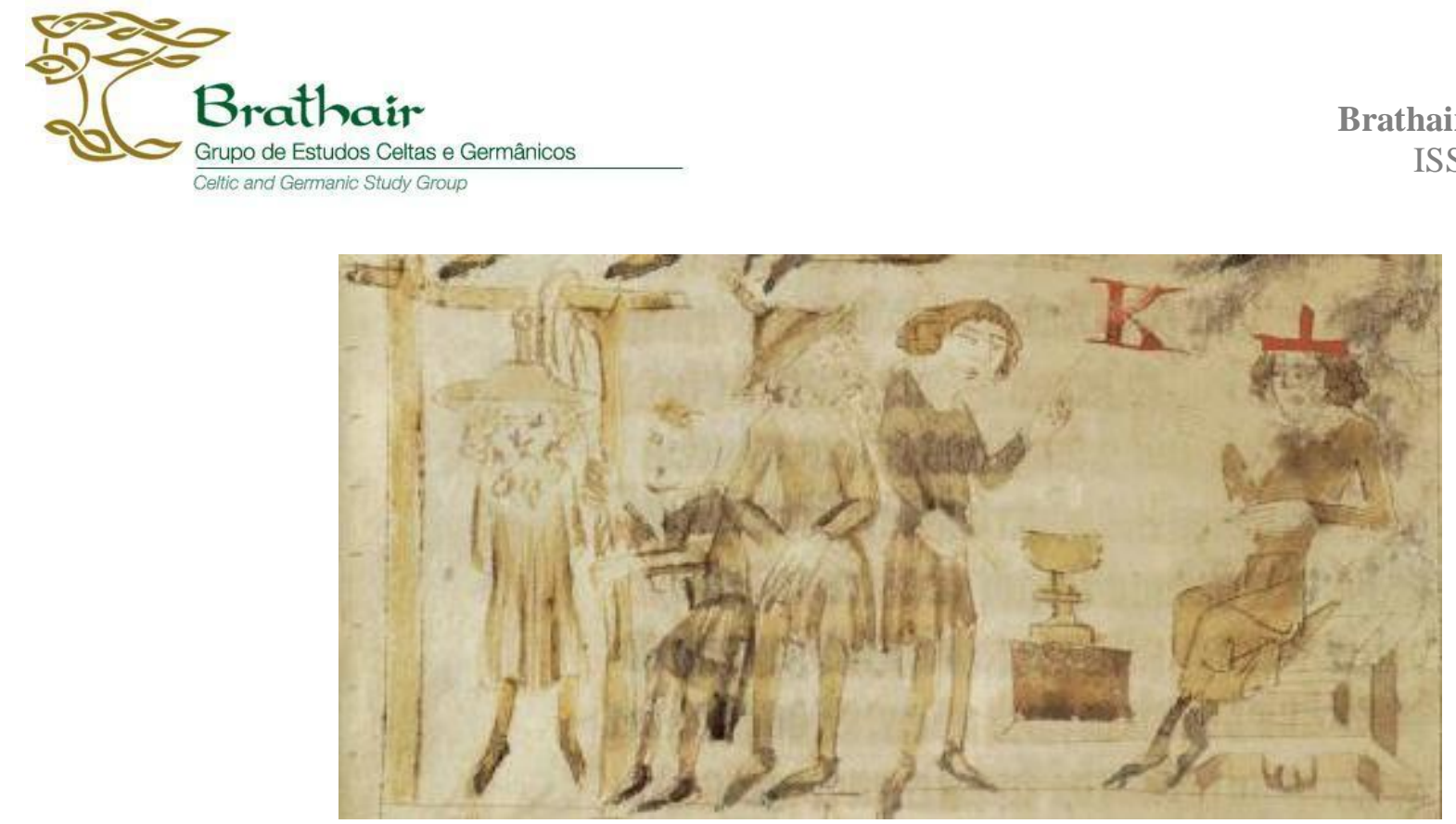

Fig. 14 - MS. D fol. 37v, picture strip no. 4

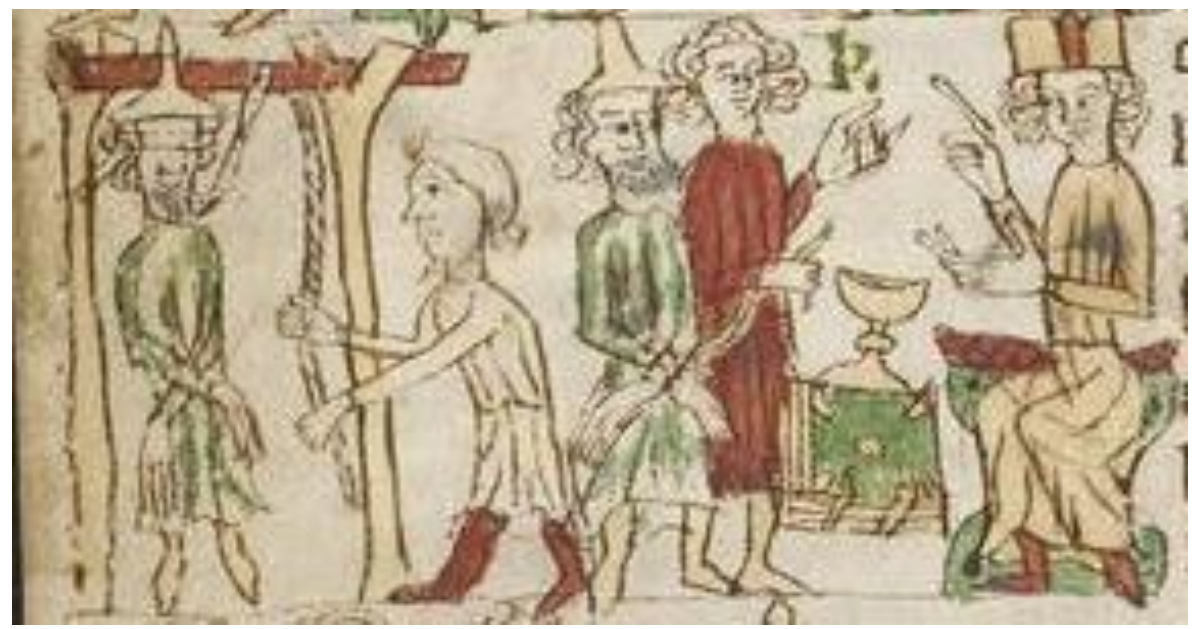

Fig. 15 - MS. H fol. 13v, picture strip no. 4

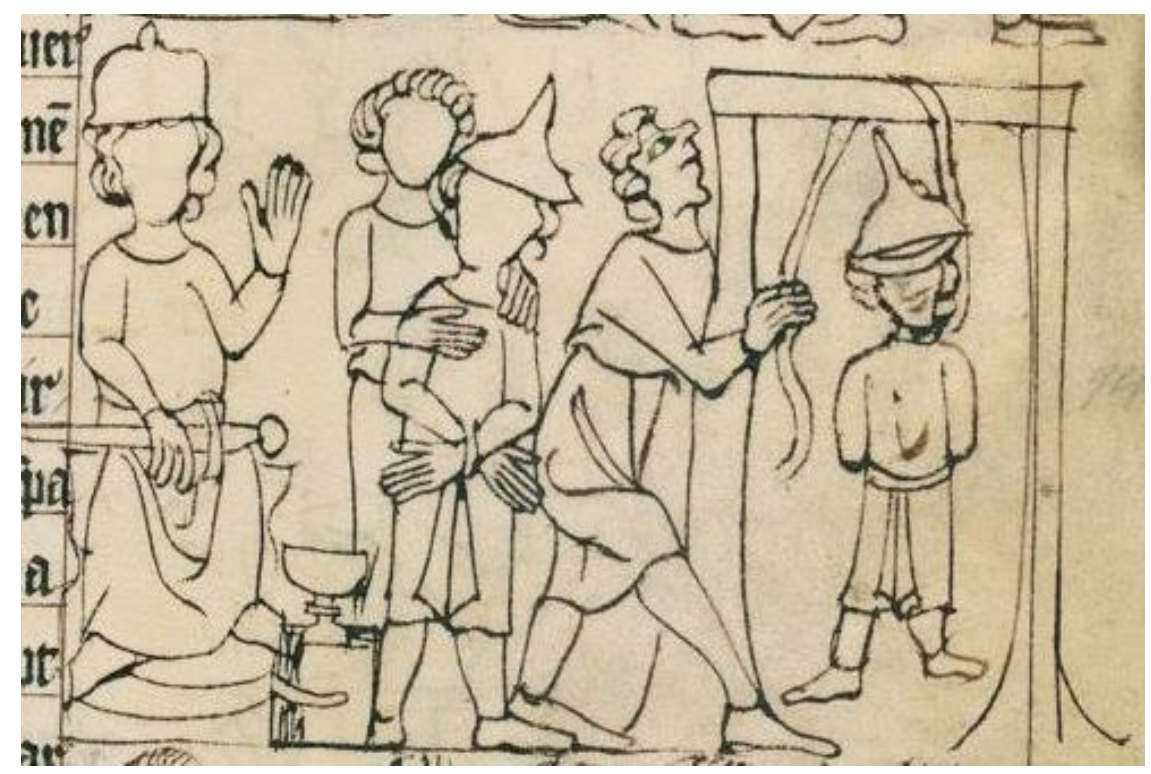

Fig. 16 - MS. O fol. 66r, picture strip no. 2 


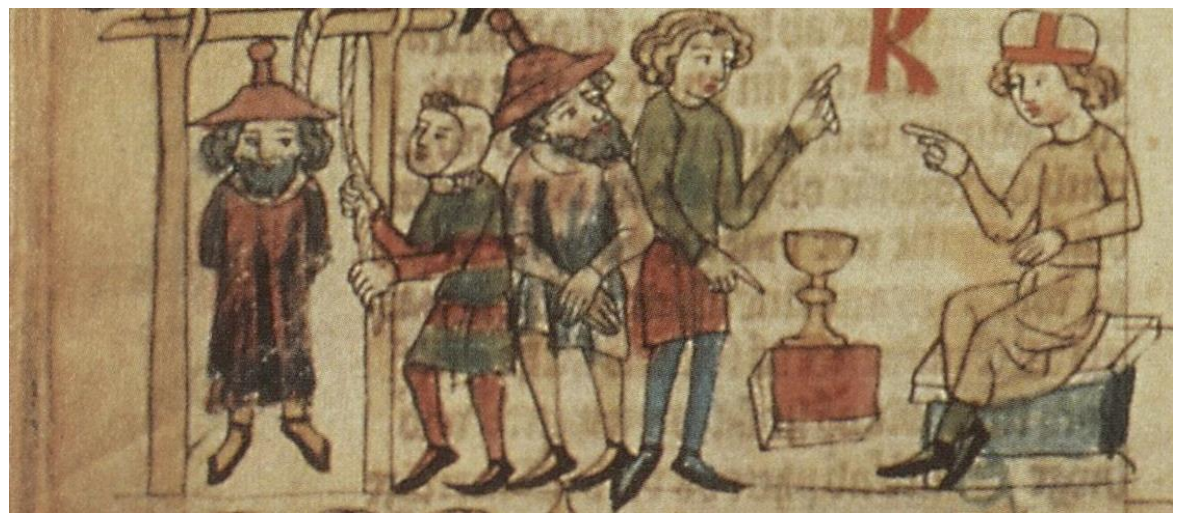

Fig. 17 - MS. W fol. 43v, picture strip no. 4

\title{
Notas
}

\begin{abstract}
${ }^{1}$ Dresden, Sächsische Landesbibliothek Ms. M 32; reproductions in facsimile: von AMIRA (ed.), 1902, see also http://digi.ub.uni-heidelberg.de/diglit/amira1902bd1/0001); LÜCK (ed.), 2006.

${ }^{2}$ Heidelberg, Universitätsbibliothek Cod. Pal. Germ 164; reproduction in facsimile KOCHER MUNZEL-EVERLING (eds.) ,2009, see also http://digi.ub.uni-heidelberg.de/diglit/cpg164.

${ }^{3}$ Oldenburg, Landesbibliothek, CIM I 410 (olim Oldenburg, Großherzogliche Privatbibliothek A,1,1), see also http://digital.lb-oldenburg.de/ssp/nav/classification/137692.
\end{abstract}

4 Wolfenbüttel, Herzog August Bibliothek cod. Guelf. 3.1.Aug fol., see also http://diglib.hab.de/?db=mss\&list=ms\&id=3-1-aug-2f.; reproduction in facsimile SCHMIDT-WIEGAND (ed.), 1993.

${ }^{5}$ For example, according to the Lex Romana Burgundionum (IV 3), the theft of a plough horse or two oxen or two mares is punishable by death. A similar disposition is found in the Lex Burgundionum (IV 1): here the death penalty is applied for the theft of a horse or an ox.

${ }^{6}$ See the overview in SCHEELE, 1992: 199-205. Already ZILLGEN, 1940: 35-36, points out that in Germanic and early German law texts the idea of the infringement of a truce almost always plays a role in the classification of a theft as major theft.

${ }^{7}$ With regard to the illustrated manuscripts of the Sachsenspiegel in general, see, among others: KOCHER, 1981; ENGELS, 1986; OTT, 1986; SCHMIDT-WIEGAND - HÜPPER (eds.), 1991; KNOLLMANN, 1998; HÜPPER, 1999; MARGADANT, 2000; MANUWALD, 2007; MANUWALD, 2009; HAYDUK, 2011; SCHEELE, 2011.

${ }^{8}$ In $\mathrm{H}$, the corresponding passage is missing.

${ }^{9}$ Not stripping the thief before hanging him is considered a more recent legal custom, see von AMIRA, 1925: 348.

${ }^{10}$ This involvement of the Lord in the servant's legal situation has been explained by the fact that the lord's immaterial interests are violated by a breach of the gewere to his servant's detriment, cf. HIRSCHBERG, 1934: 190.

${ }^{11}$ The servant's innocence is particularly emphasized in $\mathrm{O}$, where he is shown sleeping under a sky depicted with a moon and stars, that is, at a time when he is allowed to sleep. To this pictorial exemplification of the guiltlessness of the stolen, see also von AMIRA, 1925: 464-465.

${ }^{12}$ On the limited legal capacity of servants back in the days of Eike von Repgow, see FRIESE, 1898: 5464.

${ }^{13}$ If one wants to interpret these four coins as four shillings, the value of the horse is equated here by the illustrator with that of a stolen bovine, while the legal text of the Sachsenspiegel indicates the wergild rates depending on the type of horse: according to lantrecht III 51, 1, a foal has a value of 4 pennies, aa young plough horse is worth 8 shillings, a fully operational plough horse 12 shillings, the equestrian horse of a ministeriale one pound. For all other types of horse, no quota is fixed; compensation shall be paid according to the owner's estimate.

${ }^{14} \mathrm{In} \mathrm{H}$, the corresponding passage is missing.

${ }^{15}$ von AMIRA, 1925: p. 384 explains this by compositional reasons: a criminal who already hangs from the gallows can no longer be represented as a thief caught in flagranti with the stolen items in hand.

${ }^{16}$ As to the legal situation of offences involving sacred objects, see BECKER, 1990. 